\title{
The Effects of CSR Input on Valuation and Accounting Quality -- Biotechnology and Medical Industries
}

\author{
Ling-Hui Cho ${ }^{1}$, Li-Kai Liao ${ }^{2}$ \\ ${ }^{1}$ Yung Zip Chemical Ind. Co., Ltd., Taichung, Taiwan \\ ${ }^{2}$ Department of Accounting, Tunghai University, Taichung, Taiwan
}

Email address:

lingo_cho@yahoo.com.tw (Ling-Hui Cho), 1liao@thu.edu.tw (Li-Kai Liao)

\section{To cite this article:}

Ling-Hui Cho, Li-Kai Liao. The Effects of CSR Input on Valuation and Accounting Quality -- Biotechnology and Medical Industries. Journal of Finance and Accounting. Vol. 4, No. 3, 2016, pp. 146-156. doi: 10.11648/j.jfa.20160403.17

Received: April 22, 2016; Accepted: May 9, 2016; Published: May 25, 2016

\begin{abstract}
This paper examines the effects of the corporate social responsibility (CSR) input on company's valuation and accounting quality by using the samples of biotechnology and medical industries. After considering the interaction term between the accounting quality and CSR, this paper further examine whether the companies which input higher CSR will not be wrong valuation from the market. The findings show that the companies with a higher CSR, their stock prices are less likely to be underpriced by the market. The companies with higher prior period's CSR have better current period's accounting quality. After controlling for the interaction between accounting quality and CSR, the companies which input higher CSR at current and lagged-one periods are less likely to be under-valuation by the market.
\end{abstract}

Keywords: Corporate Social Responsibility, Accounting Quality, Mispricing, Business Valuation

\section{Introduction}

The rise of the corporate social responsibility (CSR) issues in the business world results in the practitioner and academia lively discussion, and it's also the effectiveness of promoting internationally the corporate governance and social responsibility for many years. All the time being, whether the company should take social responsibility and should bear the social responsibility issues such as the scope and objects, academics and practitioners have different views. Classical economist Friedman in [14] argues that only social responsibility of a company is to seek to maximize profits for shareholders. On the other hand, Bowen in [3], the father of CSR suggests that the enterprise's obligations should be seeking and satisfying all the social values of activity, and contributing to the community is also the duties and obligations of companies, which is the basis for stakeholders' concept. However, from the view point of the CSR, companies should not simply be responsible only to their shareholders, but should be responsible for all levels of the interested parties, for example, customers, employees, vendors, the community, and related environment. Under the framework of sustainable development, companies should be trying to seeking recognition at all levels of the interested parties, to achieve the economic and overall social and environment a win-win goal. In the practical side, this CSR has a proper noun, called "Sustainability".

Reference [15] uses the concept of interested parties to elaborate CSR, and points out that CSR objects should include the effects of organizational goals, or be affected by organizational goals by any group or individual; for example, employees, suppliers, customers, competitors, government, the general public, and so on. Reference [4] compares to CSR to a pyramid, from top to bottom are: charitable responsibility, moral responsibility, legal responsibility, and economic responsibility, these four overall responsibilities of an enterprise's social responsibility. To ensure the sustainable development of companies, the enterprise's decision should be trying to meet the needs of all interested parties at the same time, can stabilize the business operations, and have the support of the community.

On the other hand, reference [7] adopt the companies, which are the first time to reveal their CSR report, as the study samples, and find that companies' voluntarily disclosure for the CSR can reduce the cost of capital. Reference [9] find that, whether the national-level data or company-level data, the CSR reporting and financial cost are more important for the 
companies whose earnings information is more obscure. Reference [6] point out that there is a significantly and negatively association between the CSR performance and the information asymmetry of a company. Thereby infer that when the company's CSR is higher, the outsiders or the parties usually have more positive assessment for the company, the companies are more likely to borrow money, relatively, and they are less likely to engage in earnings management behavior. Accordingly, the effects of the CSR on the accounting quality and the company valuation are worthy of further investigations.

In recent years, biotechnology and pharmaceutics industries are flourishing because of biotechnology advances; therefore, the biotech industry is regarded as an emerging star industry in the twenty-first century, and more scholars compared to the twenty-first century is the new era of biotechnology. Under the government actively promoting and hard working in Taiwan, the biotechnology industry has been enlisted as one of the key development of the industry two mega of binary stars. For investors, how to properly evaluate the determinants of the value of the biotech industry is a very important issue. The structure of the biotech industry is complex, with highly educated, high-risk, long product development cycles, and other industrial properties, so that a substantial increase in the difficulty of investment and development of its industry. Therefore, this paper also attempts to obtain a valuation model for biotechnology and pharmaceutical industries.

Concretely speaking, this study first investigates that whether the companies with a higher CSR, their stock price will not be underpriced by the market. Secondly, we analyze that whether the companies with a higher CSR, their accounting quality will be better. Finally, after considering the interaction term between companies' accounting quality and CSR, this paper also examines whether the companies which input higher CSR will not be wrong evaluated from the market investors.

The previous literature mostly focus on the relationship between CSR and financial performance (in [24]), less analyze the impact of the companies CSR disclosed on mispricing. Reference [5] examine the financial performance and stock price issues for the companies that engage in CSR work, but they do not analyze the issues of business valuation and mispricing of CSR companies. Recently, reference [7] explore the relationship between the voluntarily disclosure of the company's CSR report and the cost of capital. Reference [9] use national-level data and company-level data to analyze the relationship between the CSR reports and capital costs for earnings information fuzzy companies. Reference [6] analyze the relationship between CSR performance and the information asymmetry of the company. However, our paper will further verify the relationship between the CSR input and company valuation and accounting quality.

Therefore, the results of this paper will enable companies to understand their social responsibility efforts to deal with as detailed disclosure for interested parties, and then to reduce the information asymmetry between the external interested parties and the managements. In other words, the companies fulfill their social responsibility have a positive meaning, and enhance the company's image.

The remainder of this paper is organized as follows: Section 2 presents the literature review and hypotheses. Section 3 explains the research design, research periods, sampling criteria and variable definitions and proposes the empirical models. Section 4 summarizes the empirical findings. The conclusion and suggestions are provided in Section 5.

\section{Literature and Hypothesis Development}

The CSR input can reduce agency costs by increasing the reputation of a company, reducing agency problems and overseeing corporate governance. Reference [13] indicates that the companies engaged in CSR helps to establish a good reputation and reduces agency costs. If they are not engaged in CSR, companies will bring the risk for reputation. Reference [1] indicate that the extent of the company emphasizing on social responsibility can be regarded as the performance that the companies establish and maintain a good reputation thereby to influence investors' view on the company's market valuation. Reference [26] point out that the companies with better morals will use part of the idle resources to do something good for the community, making those resources to perform its function, to increase their market competitiveness. Reference [22] indicate that the companies generated CSR reputation can reduce financial risk and corporate agency costs and make the companies decline to the influence caused by negative affairs lowest to ensure the value of company. Reference [23] points out that consumers would think that good CSR performance of the companies are more honest, and are confident on the quality of their products. In terms of functionality supervision, reference [20] indicate that sustainability management is a critical strategy management, which can be used to monitor and track the performance of corporate governance that the information of companies can be passed by CSR to the public, and thus enhances investor confidence in the companies.

On the other hand, reference [2] indicate that the companies whose stocks are undervalued will take advantage of the mispricing opportunity to repurchase stocks, and the stocks are overvalued companies will take advantage of this opportunity to issue stocks. Reference [11] find that, when the stocks are overvalued in the market, the companies will issue stocks. Reference [12] point out that the mispricing is a key factor in a company's equity financing decisions. Reference [16] also indicate that the company will hold most of the funds in the form of cash after the seasoned equity offering, and it engages in seasoned equity offering when the stock price of company is high. It can be seen, the stock price tends to be mispriced if the investors are irrational, and when the company's stock is overvalued by investors mispricing, the lower cost of equity financing, it will helps managers engage in equity financing to raise funds. Accordingly, this study infers that when the company has higher CSR input, 
investors usually have higher valuation for the company, so that they are more unlikely to mispricing for the company value. Therefore, we propose the following hypothesis:

H1: The companies with a higher CSR input, their stock prices are more unlikely to be underpriced by the market.

Reference [7] use the companies of the first time CSR reports release as the study samples, and find that companies voluntarily disclose CSR reports can reduce the cost of capital. Reference [8] find that the use of cross-national level data, the CSR reports will enhance the ability of securities analysts earnings forecast, and when the study samples are divided into both better transparency countries and poor transparency countries, the benefits of CSR reports in information transparency will be more important in poor transparency countries. Reference [9] find that regardless of national-level data or company-level data, for the more obscure companies of earnings information, there is more important relationship between CSR reports and the cost of capital. Reference [6] show a significant negative association between CSR performance and information asymmetry of company.

On the other hand, reference [29] point out that great corporate governance mechanism can effectively inhibit the current period's accruals, so our paper also use abnormal accruals to measure accounting quality. Reference [18] find that the conservatism of accounting can reduce managers' earnings management, making information transparency and improve the company's value. Reference [19] indicate that the worse of the accounting quality companies, it will be increase the issue cost of the company on fundraising activities, such as underwriting costs paid to the underwriters. Reference [21] also point out that, reference [10]'s earnings quality basically meaning the accounting earnings by the sum of the operating cash flow and accruals. Therefore, the quality of earnings is mainly determined by the quality of accruals. Reference [17] indicate that either the accrual-based or the real activities earnings management, the poor CSR performance of the companies will increase their earnings management behavior. At the same time, the possibility that underperforming companies CSR will be investigated by SEC is also higher.

Empirically, most of the literatures adopt the absolute value of abnormal accruals to measure the accounting quality or auditing quality, when the absolute value of abnormal accruals is higher, the accounting quality is lower and corporate governance is poorer. Therefore, this study uses the absolute value of abnormal accruals to measure the quality of accounting, whereby as a proxy of the corporate governance of good and bad. We expect that when the CSR are higher, the interested party generally has a more positive assessment for the companies and the companies are more likely to borrow capitals. In contrast, they are less likely to engage in earnings management behavior; therefore, they have a better accounting quality. Accordingly, we propose the following hypothesis:

$\mathrm{H}$ 2: The companies which input the higher CSR, their accounting qualities will be better.
In addition, this paper will further consider the role of the interaction between accounting quality and CSR on the relation between CSR and mispricing. The possible reason is that the firm with higher CSR input has higher transparency, so analysts and investors can get more information and then a rational evaluation for the firm value. We form the following hypothesis:

H3: The CSR will affect the relationship between accounting quality and mispricing.

\section{Research Design}

\subsection{The Data}

This paper focuses on the public listed and OTC companies in the Biotechnology and Medical Industries. Since 2009 to 2015 a number of best-selling biotechnology drugs expiring patent protection, improvement of process technology and policy support in Europe, American and emerging markets, resulting in significant increase in the growth potential of the global biotech generics. The initial sample is drawn from the Taiwan Economic Journal (TEJ) database for the period 2009 to 2013 . We summarize the sample selection criteria in Table 1. From Table 1, the initial sample size is 287 and we delete 49 samples that were missing details or that were discontinuous or invalid. Our final sample consists of 238 firm-year observations.

Table 1. Sample Selection.

\begin{tabular}{ll}
\hline Initial sample & 287 \\
Delete the data are missing or invalid & 49 \\
Final Sample (2009-2013) & 238 \\
\hline
\end{tabular}

\subsection{Empirical Model}

This paper first applies OLS model to examine the Hypothesis 1, that is, the companies with a higher CSR, their stock prices will not be mispricing by the market. To avoid the problem of endogeneity, we also consider the effects of previous period's mispricing and previous period's CSR input on current period's mispricing of a firm.

$$
\begin{aligned}
& \text { Misprice }_{i t}=a_{0}+a_{1} \text { CSR }_{i t-1}+a_{2} \text { ROA }_{i t}+a_{3} \text { Lever }_{i t} \\
& +a_{4} M B_{i t}+a_{5} \text { Beta }_{i t}+a_{6} \text { Size }_{i t} \\
& +a_{7} \mathrm{OCF}_{i t}+a_{8} M_{-} \text {Stock }_{i t} \\
& +a_{9} D_{-} \text {Rate }_{i t}+\text { Year }+e_{i t} \\
& \text { Misprice }_{i t}=a_{0}+a_{1} \text { CSR }_{i t}+a_{2} \text { ROA }_{i t}+a_{3} \text { Lever }_{i t} \\
& +a_{4} M B_{i t}+a_{5} \text { Beta }_{i t}+a_{6} \text { Size }_{i t} \\
& +a_{7} O C F_{i t}+a_{8} M_{-} \text {Stock } \\
& +a_{9} D_{-} \text {Rate }_{i t}+\text { Year }+e_{i t} \\
& \text { Misprice }_{i t}=a_{0}+a_{1} \text { CSR }_{i t-1}+a_{2} \text { Misprice }_{i t-1}+a_{3} \text { ROA }_{i t} \\
& +a_{4} \text { Lever }_{i t}+a_{5} M B_{i t}+a_{6} \text { Beta }_{i t}+a_{7} \text { Size }_{i t} \\
& +a_{8} O C F_{i t}+a_{9} M_{-} \text {Stock }_{i t} \\
& +a_{10} D_{-} \text {Rate }_{i t}+\text { Year }+e_{i t}
\end{aligned}
$$




$$
\begin{aligned}
\text { Misprice }_{i t} & =a_{0}+a_{1} \text { CSR }_{i t}+a_{2} \text { Misprice }_{i t-1}+a_{3} \text { ROA }_{i t} \\
& +a_{4} \text { Lever }_{i t}+a_{5} M B_{i t}+a_{6} \text { Beta }_{i t} \\
& +a_{7} \text { Size }_{i t}+a_{8} \text { OCF }_{i t}+a_{9} M_{-} \text {Stock }_{i t} \\
& +a_{10} D_{-} \text {Rate }_{i t}+\text { Year }+e_{i t}
\end{aligned}
$$

where Misprice is the measure of mispricing. CSR is the input of CSR (Social contribution value per share), which is the sum of the net income, salaries to employees, tax payments, interest expenses and donations minus total social cost, scaled by share number of outstanding. ${ }^{1}$ ROA is the return on assets, measured by income before interest divided by the total assets at the ending-year, which represent the profitability of a firm. Financial leverage (Lever) is debt to equity ratio, measured by long-term liabilities divided by the total assets at the ending-year. MB is a firm's growth opportunity, which is defined as the market-to-book ratio, measured with the market value of equity divided by the book value of equity. The managerial risk attitudes are studied indirectly through a variable of a firm's risk, given that determine the firm's overall risk exposure. In this paper study, as a measure of risk we use the market risks (Beta), calculated with CAPM. Size is the firm size, which is natural $\log$ of market value of equity at the end of the fiscal year. Operating cash flow $(O C F)$ is calculated as the ratio of cash flow from operations to the total assets at the beginning of the year. M_Stock is the shareholdings of managers. D_Rate is the ratio that a director is also a manager.

Next, we examine the Hypothesis 2, which is to investigate whether the companies which into the higher CSR, their accounting quality will be better. To avoid the endogeneity problem, this paper also examine the effects of previous period's accounting quality and previous period's CSR input on current period's accounting quality of a firm. Hence, the specification is as follows:

$$
\begin{aligned}
A Q_{i t} & =a_{0}+a_{1} \text { CSR }_{i t-1}+a_{2} A Q_{i t-1}+a_{3} \text { ROA }_{i t} \\
& +a_{4} \text { Lever }_{i t}+a_{5} M B_{i t}+a_{6} \text { Beta }_{i t} \\
& +a_{7} \text { Size }_{i t}+a_{8} \text { OCF }_{i t}+a_{9} M_{-} \text {Stock }_{i t} \\
& +a_{10} D_{-} \text {Rate }_{i t}+\text { Year }+e_{i t} \\
A Q_{i t} & =a_{0}+a_{1} \text { CSR }_{i t}+a_{2} \text { ROA }_{i t}+a_{3} \text { Lever }_{i t} \\
& +a_{4} M B_{i t}+a_{5} \text { Beta }_{i t}+a_{6} \text { Size }_{i t} \\
& +a_{7} \text { OCF }_{i t}+a_{8} M_{-} \text {Stock }_{i t} \\
& +a_{9} D_{-} \text {Rate }_{i t}+\text { Year }+e_{i t}
\end{aligned}
$$

1 In 2008, the SSE issued the "Notice on Strengthening Listed Companies' Assumption of Social Responsibilities" and the "Guidelines on Environment Information Disclosure by Listed Company". The SSE provided the new concept of the social contribution value per share (SCVPS) to measure companies' value creation for society and shareholders. In 2009, the SSE released a third sustainability document, "Compilation Guideline for the 'Reports on Fulfillment of Social Responsibilities" prescribing all companies disclosing on SCVPS to provide an explanation of the calculation of the score. The SSE believes that SCVPS can let the public to understand the value creation of companies for the shareholders, employees, customers, creditors, communities, and society.

$$
\begin{aligned}
A Q_{i t} & =a_{0}+a_{1} \text { CSR }_{i t-1}+a_{2} A Q_{i t-1}+a_{3} \text { ROA }_{i t} \\
& +a_{4} \text { Lever }_{i t}+a_{5} M B_{i t}+a_{6} \text { Beta }_{i t} \\
& +a_{7} \text { Size }_{i t}+a_{8} \text { OCF }_{i t}+a_{9} M_{-} \text {Stock }_{i t} \\
& +a_{10} D_{-} \text {Rate }_{i t}+\text { Year }+e_{i t} \\
A Q_{i t} & =a_{0}+a_{1} \text { CSR }_{i t}+a_{2} A Q_{i t-1}+a_{3} \text { ROA }_{i t} \\
& +a_{4} \text { Lever }_{i t}+a_{5} M B_{i t}+a_{6} \text { Beta }_{i t} \\
& +a_{7} \text { Size }_{i t}+a_{9} O C F_{i t}+a_{9} M_{-} \text {Stock }_{i t} \\
& +a_{10} \text { D_Rate }_{i t}+\text { Year }+e_{i t}
\end{aligned}
$$

where AQ is the accounting quality, CSR is the input of CSR, $\mathrm{ROA}$ is the return of assets, Lever is the financial leverage ratio, $\mathrm{MB}$ is the growth opportunity of a firm, Beta is the systematic risk of firm, Size is the firm size, OCF is the operating cash flows, M_Stock is the shareholdings of managers, and D_Rate is the ratio that a director is also a manager.

Moreover, under considering the interaction between accounting quality and CSR of a company, this paper also examine whether the companies which input higher CSR will not be mispricing by the market investors (H3).

$$
\begin{aligned}
& \text { Misprice }_{i t}=a_{0}+a_{1} \operatorname{CSR}_{i t}+a_{2} A Q_{i t}+a_{3} \operatorname{CSR}_{i t} A Q_{i t} \\
& +a_{4} R O A_{i t}+a_{5} \text { Lever }_{i t}+a_{6} M B_{i t} \\
& +a_{7} \text { Beta }_{i t}+a_{8} \text { Size }_{i t}+a_{9} \text { OCF }_{i t}+a_{10} M_{-} \text {Stock }_{i t} \\
& +a_{11} D_{-} \text {Rate }_{i t}+\text { Year }+e_{i t} \\
& \text { Misprice }_{i t}=a_{0}+a_{1} \operatorname{CSR}_{i t-1}+a_{2} A Q_{i t}+a_{3} \operatorname{CSR}_{i t-1} A Q_{i t} \\
& +a_{4} R O A_{i t}+a_{5} \text { Lever }_{i t}+a_{6} M B_{i t} \\
& +a_{7} \text { Beta }_{i t}+a_{8} \text { Size }_{i t}+a_{9} O C F_{i t}+a_{10} M_{-} \text {Stock }_{i t} \\
& +a_{11} D_{-} \text {Rate }_{i t}+\text { Year }+e_{i t}
\end{aligned}
$$

where $\mathrm{CSR}^{*} \mathrm{AQ}$ is the interaction term between current CSR and AQ.

\subsection{Variable Definition}

We follow reference [28] to obtain the ratio of Misprice to measure whether a firm is mispriced by the market investors. First, this paper adopts Edwards-Bell-Ohlson (EBO) valuation model to calculate the firm's intrinsic value. The model is as follows:

$$
V_{0}=B V_{0}+\sum_{t=1}^{n} \frac{\left(E_{t}-r \times B V_{t-1}\right)}{(1+r)^{t}}+\frac{T V}{(1+r)^{n} \times r}
$$

Using the following model, we can find the terminal value TV

$$
T V=\frac{\left(E_{t}-r \times B V_{t-1}\right)+\left(E_{t+1}-r \times B V_{t}\right)}{2}
$$

where $V_{0}$ is the true value of equity of a firm at period 0 , $B V_{0}$ is the book value of equity of a firm at period $0, r$ is capital cost of equity of a firm, and $E_{t}$ is expected future 
revenue of period $\mathrm{t}$ at period 0 . Note, period 0 is the beginning of fiscal year. Because $E_{t}$ is expected value, $E_{t}$ can be replaced by $R O E_{t} \times B V_{t-1}$. That is, from the view of investment, the expected future return of a firm is the stockholder's equity at the beginning year multiplied by the return of equity (ROE). Therefore, (11) and (12) can be rewritten as the following models:

$$
\begin{aligned}
& V_{0}=B V_{0}+\sum_{t=1}^{n} \frac{\left[\left(R O E_{t}-r\right) \times B V_{t-1}\right]}{(1+r)^{t}}+\frac{T V}{(1+r)^{n} \times r} \\
& T V=\frac{\left[\left(R O E_{t}-r\right) \times B V_{t-1}\right]+\left[\left(R O E_{t+1}-r\right) \times B V_{t}\right]}{2}
\end{aligned}
$$

Due to an infinite-period EBO model in above model, in theoretically, we need to estimate an infinite-period's ROEs. However, in practice, its estimation is very difficult, so that the empirical study usually change it as a finite-period model. We follow reference [28] to take $n=2$ as the forecast years, and assume the returns are fix in future continuous years. After plugging the terminal value $T V$ into (13), we can rewrite it as the following model:

$$
\begin{aligned}
V_{0}= & B_{0}+\frac{\left[\left(R O E_{1}-r\right) \times B V_{0}\right]}{(1+r)}+\frac{\left[\left(R O E_{2}-r\right) \times B V_{1}\right]}{(1+r)^{2}} \\
& +\frac{\left[\left(R O E_{2}-r\right) \times B V_{1}\right]+\left[\left(R O E_{3}-r\right) \times B V_{2}\right]}{2(1+r)^{2} \times r}
\end{aligned}
$$

where $r$ is estimated by CAPM. This paper adopt the all-inclusive concept to compute future book value of equity ( $\left.B V_{t+i}\right)$, so its computation is $B V_{t+1}=B V_{t}+N I_{t+1}-D I V_{t+1}$, where $D I V_{t+1}$ is dividend at period $\mathrm{t}+1$. Assume $D R$ is dividend payout ratio, then the computation can be written as $(1-D R) N I_{t+1}$, and then we can estimate $B V_{t+i}$ at future periods.

Second, we compute the ratio of Misprice. Plug the estimated intrinsic value at previous step (15), we can compute the following mispricing ratio, where $V_{i t}$ is intrinsic value of firm $\mathrm{i}$ at period $\mathrm{t}$ and $P_{i t}$ is stock price at the beginning period $t$.

$$
\text { Misprice }_{i t}=\frac{V_{i t}}{P_{i t}}
$$

Finally, we justify the ratio. If Misprice $=1$, the firm vale has no mispricing; If Misprice is higher than 1, the firm value has under valuation; If Misprice is lower than 1, the firm value has over valuation.

\section{Accounting quality $(A Q)$}

Institutionally, accruals not only reflect current cash flows or the reversal of previous cash flows, but only can anticipate future operating cash flows. The measurement error in computing accruals has the possibility to distort the expectation ability of accruals to future cash flows, or to distort the ability of reflecting cash flows of current and previous periods. Meanwhile, this measurement error is possibly unintentional error from operation uncertainty or management failure or intentional error from the incentive of manipulation earnings of the managers.

This paper follows reference [21], which extend reference [10] by considering two factors of sales' growth and property, plant, and equipment. The models are as follows:

$$
\begin{aligned}
T C A_{i t} & =b_{0}+b_{1} C F O_{i t-1}+b_{2} C F O_{i t}+b_{3} C F O_{i t+1} \\
& +b_{4} \Delta R E V_{i t}+b_{5} P P E_{i t}+e_{i t}
\end{aligned}
$$

where $T C A_{i t}$ is the total accruals of firm $i$ in period $\mathrm{t}$ (deflated by lagged period's total assets). $\triangle \mathrm{REV}$ is the change in net sales scaled by lagged period's total assets. PPE is the net property, plant and equipment scaled by lagged period's total assets. The residuals in model (II) are the abnormal accruals. We use the absolute of residual (AbsoResi) to measure accounting quality of financial statements.

\section{Empirical Results}

\subsection{Sample Analysis}

Table 2. Descriptive statistics.

\begin{tabular}{lllll}
\hline & Mean & Std. Dev. & Minimum & Maximum \\
\hline Misprice & 0.9208 & 0.5415 & -1.9600 & 2.3500 \\
Misprice $_{\text {it-1 }}$ & 0.9268 & 0.5258 & -1.9200 & 2.3500 \\
CSR & 5.6172 & 6.9037 & -6.2400 & 55.2000 \\
CSR $_{\text {it-1 }}$ & 5.8037 & 6.9784 & -2.3100 & 55.2000 \\
AQ & 0.0929 & 0.1508 & 0.0001 & 1.8543 \\
AQ & 0.0797 & 0.0939 & 0.0001 & 0.5460 \\
ROA & 4.2694 & 12.0576 & -64.6200 & 57.4900 \\
Lever & 0.0552 & 0.0870 & 0.0000 & 0.3900 \\
MB & 116.5378 & 66.6696 & 1.0000 & 232.0000 \\
Beta & 0.9241 & 0.3421 & -1.3500 & 2.8000 \\
Size & 17.1998 & 0.9228 & 14.9900 & 19.9880 \\
OCF & 0.0602 & 0.1099 & -0.3600 & 0.3100 \\
M_Stock & 1.4098 & 1.5078 & 0.0000 & 7.4800 \\
D_Rate & 18.8395 & 12.8772 & 0.0000 & 80.0000 \\
\hline
\end{tabular}

1. Number of observations is 238 .

2. Variable definitions:

Misprice $=$ market mispricing, $\mathrm{CSR}=\mathrm{CSR}$ input, $\mathrm{AQ}=$ accounting quality, $\mathrm{ROA}=$ return on assets, Lever $=$ financial leverage which is long-term debt divided by total assets of the ending period, $\mathrm{MB}=$ growth opportunity which is market value of equity divided by book value of equity, Beta = Beta risk, Size $=$ firm size which is natural $\log$ of market value of equity, OCF = operating cash flows which is current period's operating cash flows divided by total assets of the beginning period, M_Stock = shareholdings of managers which is the shareholdings of corporate managers or group firm's managers, D_Rate $=$ the ratio of a director concurrently served as a manager which is the number of director concurrently served as a manager divided by total numbers of directors.

Table 2 presents the description statistics of variables. In Table 2, the mean value of Misprice 0.9208 indicates that the stock prices of the biotechnology and medical industries are generally overvalued. The maximum and minimum values of CSR are approximately 55 and -6 , which implies that the input of CSR of sample companies differs a lot. The range of accounting quality (AQ) is about 0 to 1.9 , meaning that 
accounting qualities of firms within biotechnology and medical industries have a deviation. However, the mean value of AQ 0.0929 means that on average, there are better accounting quality in biotechnology and medical industries samples. The range of ROA is approximately from -64 to 57 and its mean value is about to 4 , meaning that the operating performances have great difference between each biotechnology and medical companies.

The main purpose of correlations analysis can help us to understand the degree of relationship between two independent variables, and avoid the consequence of multicollinearity. Reference [25] indicate that if the correlation coefficients are less than 0.65 , it means that between variables is independence without collinearity. In our untabulated results, multicollinearity does not exist because the correlation coefficients of all pairwise variables are less than 0.65 .

\subsection{The Relationship Between Prior CSR Input and Mispricing}

In Table 3, we adopt examine the relationship between prior period CSR input and market mispricing, in which current period market mispricing is denoted by Misprice ${ }_{i t}$ and $\mathrm{CSR}_{\mathrm{it}-1}$ is the prior period's CSR cost. In Model 1 of Table 3, the findings show that market mispricing (Misprice) is significantly and negatively related to prior period's CSR cost $\left(\mathrm{CSR}_{\mathrm{it}-1}\right)$, implying that companies are more unlikely to be undervalued at current period by market investors if companies input higher CSR at prior period. The possible reason is that the firm with higher CSR input generally has higher transparency and reputation, that is, lower information asymmetry, so that the security analysts or investors can make more precisely valuation for the firm. As a result, the empirical results are consistent with our expectations.

As for the control variables, the relation between market mispricing (Misprice) and the ratio of directors concurrently served as a managers (D_RATE) is significantly and negatively correlated, showing that the higher ratio of directors concurrently served as a managers, the company stock price is not more likely to be undervalued by the market.

Considering the endogeneity problem of market mispricing, this study adds prior period's market mispricing as an explanatory variable in Model 1a to analyze its effect on current market mispricing. In Model 3 of Table 3, prior period CSR cost is denoted by $\mathrm{CSR}_{\mathrm{it}-1}$ and prior period's market mispricing is denoted as Misprice $_{i t-1}$. Based on empirical results, market mispricing (Misprice) are significantly and negatively correlated to prior period's CSR cost $\left(\mathrm{CSR}_{\mathrm{it}-1}\right)$, and it means that companies which input more prior period CSR cost are more unlikely to be undervalued. The rational explanation is that under considering prior mispricing, the firm with higher CSR input has lower information asymmetry, so that the financial analysts or investors can make more correctly valuation for the firm.

Overall, both Models 1 and 3 in Table 3 show that higher the companies with prior period's CSR input, and the current stock price of a firm is less likely mispricing and under-valued and therefore, our result supports the hypothesis 1 .

Table 3. The relationship between prior CSR input and corporate mispricing.

\begin{tabular}{|c|c|c|c|c|c|c|}
\hline \multirow{2}{*}{ Variables } & \multicolumn{3}{|l|}{ Model 1} & \multicolumn{3}{|l|}{ Model 3} \\
\hline & Coef. & t value & $P>t$ & Coef. & t value & $\mathbf{P}>\mathbf{t}$ \\
\hline Misprice $_{\mathrm{it}-1}$ & & & & 0.0006 & 0.44 & 0.6640 \\
\hline $\mathrm{CSR}_{\mathrm{it}-1}$ & -0.0160 & -2.31 & 0.0220 & -0.0081 & -2.35 & 0.0200 \\
\hline ROA & 0.0036 & 0.62 & 0.5370 & 0.0003 & 0.68 & 0.4960 \\
\hline Lever & 0.4197 & 0.99 & 0.3240 & -0.0053 & -0.16 & 0.8760 \\
\hline MB & 0.0009 & 1.80 & 0.0730 & 0.0010 & 2.13 & 0.0340 \\
\hline Beta & 0.2022 & 1.48 & 0.1410 & 0.0118 & 1.07 & 0.2880 \\
\hline Size & 0.0283 & 0.56 & 0.5770 & -0.0031 & -0.78 & 0.4390 \\
\hline OCF & -0.6180 & -1.04 & 0.3020 & -2.5811 & -2.80 & 0.0050 \\
\hline M_Stock & 0.0462 & 1.77 & 0.0780 & -0.0003 & -0.16 & 0.8710 \\
\hline D_Rate & -0.0075 & -2.38 & 0.0180 & -0.0019 & -3.15 & 0.0020 \\
\hline _Cons & 0.7088 & 0.83 & 0.4060 & 0.0574 & 0.84 & 0.4020 \\
\hline No. of obs. & 238 & & & 238 & & \\
\hline Prob $>F$ & 0.0000 & & & 0.0000 & & \\
\hline R-squared & 0.1450 & & & 0.0403 & & \\
\hline Adj R-squared & 0.0941 & & & 0.0404 & & \\
\hline
\end{tabular}

Variable definition:

Misprice $_{\mathrm{it}-1}=$ prior period's market mispricing, $\mathrm{CSR}_{\mathrm{it}-1}=$ prior period's CSR input, $\mathrm{ROA}=$ return on assets, Lever $=$ financial leverage which is long-term debt divided by total assets of the ending period, $\mathrm{MB}=$ growth opportunity which is market value of equity divided by book value of equity, Beta $=$ Beta risk, Size = firm size which is natural log of market value of equity, $\mathrm{OCF}=$ operating cash flows which is current period's operating cash flows divided by total assets of the beginning period, M_Stock = shareholdings of managers which is the shareholdings of corporate managers or group firm's managers, D_Rate = the ratio of a director concurrently served as a manager which is the number of director concurrently served as a manager divided by total numbers of directors. 


\subsection{The Relation Between Current CSR Cost and Mispricing}

In Table 4, we analyze the relationship between current CSR cost and market mispricing. From Model 2 of Table 4, the findings show that market mispricing is significantly and negatively related to current period's input of CSR (CSR), showing that the higher current CSR cost the companies have, the less chance the stock value to be under-valued by market. As for the control variables, the relation between market mispricing (Misprice) and the ratio of directors concurrently served as a managers (D_RATE) is significantly and negatively correlated, showing that the higher ratio of directors concurrently served as a managers, the less likely a company stock price to be market overvalued. Overall, the
Model 2 suggests that the higher degree of CSR the companies input, the less susceptible the companies to be undervalued and therefore, the result supports hypothesis 1 .

Considering endogeneity problem in market mispricing, this study adds prior period market mispricing in Model 4 as an explanatory variable to analyze its effect on current market mispricing. In Model 4 of Table 4, current mispricing is significantly and positively related to prior mispricing, implying that higher prior mispricing is, the more susceptible the companies to be mispriced. Meanwhile, from empirical results, we also find that after considering prior mispricing, current mispricing is negatively related to current period's CSR input.

Table 4. The relation between current CSR cost and market mispricing.

\begin{tabular}{|c|c|c|c|c|c|c|}
\hline Variables & \multicolumn{3}{|l|}{ Model 2} & \multicolumn{3}{|l|}{ Model 4} \\
\hline Misprice $_{\mathrm{it}-1}$ & & & & 0.0009 & 0.66 & 0.5130 \\
\hline CSR & -0.0167 & -2.66 & 0.0080 & -0.1192 & -4.20 & 0.0000 \\
\hline ROA & 0.0088 & 1.67 & 0.0960 & 0.0003 & 0.65 & 0.5170 \\
\hline MB & 0.0010 & 1.89 & 0.0600 & 0.0000 & 0.18 & 0.8550 \\
\hline Beta & 0.1855 & 1.88 & 0.0610 & 0.0118 & 1.07 & 0.2850 \\
\hline Size & 0.0104 & 0.24 & 0.8100 & -0.0026 & -0.73 & 0.4660 \\
\hline OCF & -0.9293 & -1.83 & 0.0690 & -0.0184 & -0.39 & 0.6950 \\
\hline M_Stock & 0.0369 & 1.68 & 0.0950 & -0.0019 & -3.15 & 0.0020 \\
\hline D_Rate & -0.0078 & -2.96 & 0.0030 & -0.0001 & -0.24 & 0.8100 \\
\hline Year & -0.0456 & -1.86 & 0.0640 & -0.0034 & -1.19 & 0.2340 \\
\hline No. of obs. & 238 & & & 238 & & \\
\hline Prob $>F$ & 0.0000 & & & 0.0000 & & \\
\hline R-squared & 0.1568 & & & 0.0403 & & \\
\hline Adj R-squared & 0.1611 & & & 0.0408 & & \\
\hline
\end{tabular}

Variable definition:

Misprice $_{\mathrm{it}-1}=$ prior period's market mispricing, $\mathrm{CSR}_{\mathrm{it}}=$ current period's CSR input, $\mathrm{ROA}=$ return on assets, Lever $=$ financial leverage which is long-term debt divided by total assets of the ending period, $\mathrm{MB}=$ growth opportunity which is market value of equity divided by book value of equity, Beta $=$ Beta risk, Size $=$ firm size which is natural log of market value of equity, $\mathrm{OCF}=$ operating cash flows which is current period's operating cash flows divided by total assets of the beginning period, M_Stock = shareholdings of managers which is the shareholdings of corporate managers or group firm's managers, D_Rate = the ratio of a director concurrently served as a manager which is the number of director concurrently served as a manager divided by total numbers of directors.

\subsection{The Relationship Between Prior CSR and Accounting Quality}

Table 5 analyzes the association between prior period's CSR and accounting quality. From Model 5 in Table 5, we find that accounting quality is significantly and negatively related to prior CSR, showing that if companies have higher lagged period's CSR input, they have better business reputation and sound constitution, so that they do a higher accounting quality owned. The possible reason is that the effect of CSR input on company is more longer period. In other words, the empirical result is consistent with our expectation.

Considering endogeneity problem in accounting quality, this study adds prior period accounting quality in Model 7 to be regarded as an explanatory variable to examine its effect on current accounting quality. In Model 7 of Table 5, prior period accounting quality is denoted by $\mathrm{AQ}_{\mathrm{it}-1}$. We also find that there is a negative association between accounting quality and prior CSR cost, and it shows that the company which has higher prior period's CSR has a better business reputation and constitution, so it does a higher accounting quality.

From the finding of hypothesis 2 , it creates reputation effect when the year biotechnology and medical industries implement CSR and lead to further advantage of price premium. Therefore, stockholders and investors realize business value, and sustainable value recreation will enhance current and subsequent contribution margin, hence, as the view of the Fame and Profit Win-win Hypothesis, investors willing to continue to inject substantial funds. 
Table 5. The relationship between prior CSR and accounting quality.

\begin{tabular}{|c|c|c|c|c|c|c|}
\hline \multirow{2}{*}{ Variables } & \multicolumn{3}{|l|}{ Model 5} & \multicolumn{3}{|l|}{ Model 7} \\
\hline & Coef. & t value & $P>t$ & Coef. & t value & $P>t$ \\
\hline $\mathrm{AQ}_{\mathrm{it}-1}$ & & & & 0.2193 & 3.03 & 0.0030 \\
\hline $\mathrm{CSR}_{\mathrm{it}-1}$ & -0.0048 & -2.22 & 0.0270 & -0.0060 & -2.88 & 0.0040 \\
\hline ROA & -0.0015 & -1.96 & 0.0510 & -0.0011 & -1.42 & 0.1570 \\
\hline Lever & -0.0980 & -1.93 & 0.0550 & -0.0649 & -1.27 & 0.2050 \\
\hline MB & 0.0000 & 0.30 & 0.7680 & 0.0000 & -0.08 & 0.9360 \\
\hline Beta & -0.0124 & -0.54 & 0.5880 & -0.0091 & -0.40 & 0.6860 \\
\hline Size & 0.0149 & 1.76 & 0.0810 & 0.0098 & 1.16 & 0.2490 \\
\hline OCF & -0.3055 & -3.05 & 0.0030 & -0.2965 & -3.03 & 0.0030 \\
\hline M_Stock & -0.0021 & -1.95 & 0.0530 & -0.0009 & -0.82 & 0.4130 \\
\hline D_Rate & -0.0009 & -1.68 & 0.0940 & -0.0008 & -1.55 & 0.1240 \\
\hline Year & 0.0137 & 2.28 & 0.0240 & 0.0131 & 2.23 & 0.0270 \\
\hline _Cons & -0.1771 & -1.24 & 0.2160 & -0.1077 & -0.76 & 0.4460 \\
\hline No. of obs. & 238 & & & 238 & & \\
\hline Prob $>F$ & 0.0000 & & & 0.0000 & & \\
\hline R-squared & 0.2149 & & & 0.2557 & & \\
\hline Adj R-squared & 0.1681 & & & 0.2067 & & \\
\hline
\end{tabular}

Variable definition:

$\mathrm{AQ}=$ accounting quality, $\mathrm{CSR}=\mathrm{CSR}$ input, $\mathrm{ROA}=$ return on assets, Lever $=$ financial leverage which is long-term debt divided by total assets of the ending period, $\mathrm{MB}=$ growth opportunity which is market value of equity divided by book value of equity, Beta $=$ Beta risk, Size $=$ firm size which is natural log of market value of equity, $\mathrm{OCF}=$ operating cash flows which is current period's operating cash flows divided by total assets of the beginning period, M_Stock = shareholdings of managers which is the shareholdings of corporate managers or group firm's managers, D_Rate = the ratio of a director concurrently served as a manager which is the number of director concurrently served as a manager divided by total numbers of directors.

Table 6. The relationship between current CSR and accounting quality.

\begin{tabular}{|c|c|c|c|c|c|c|}
\hline \multirow{2}{*}{ Variables } & \multicolumn{3}{|l|}{ Model 6} & \multicolumn{3}{|c|}{ Model 8} \\
\hline & Coef. & t value & $\mathbf{P}>\mathbf{t}$ & Coef. & t value & $\mathbf{P}>\mathbf{t}$ \\
\hline$A Q_{i t-1}$ & & & & 0.2203 & 3.04 & 0.0030 \\
\hline CSR & 0.0019 & 2.05 & 0.0410 & 0.0019 & 1.99 & 0.0480 \\
\hline ROA & -0.0022 & -2.35 & 0.0020 & -0.0005 & -0.54 & 0.5870 \\
\hline Lever & -0.0882 & -1.32 & 0.0730 & -0.0646 & -1.25 & 0.2120 \\
\hline MB & 0.0000 & -0.36 & 0.7180 & 0.0000 & 0.03 & 0.4560 \\
\hline Beta & -0.0108 & -0.61 & 0.5430 & -0.0081 & -0.36 & 0.7190 \\
\hline Size & 0.0200 & 2.57 & 0.3170 & 0.0079 & 0.94 & 0.3470 \\
\hline $\mathrm{OCF}$ & -0.2268 & -2.48 & 0.0140 & -0.3191 & .3 .34 & 0.0010 \\
\hline M_Stock & 0.0048 & 1.22 & 0.2250 & 0.0046 & 1.08 & 0.2800 \\
\hline D_Rate & -0.0006 & -1.27 & 0.2070 & -0.0007 & -1.39 & 0.1660 \\
\hline Year & 0.0061 & 1.39 & 0.1660 & 0.0132 & 2.25 & 0.0260 \\
\hline _Cons & -0.2325 & -1.77 & 0.0790 & -0.0813 & -0.58 & 0.5600 \\
\hline No. of obs. & 238 & & & 238 & & \\
\hline Prob $>F$ & 0.0000 & & & 0.0000 & & \\
\hline R-squared & 0.1970 & & & 0.2555 & & \\
\hline Adj R-squared & 0.1582 & & & 0.2065 & & \\
\hline
\end{tabular}

Variable definition:

$\mathrm{AQ}=$ accounting quality, $\mathrm{CSR}=\mathrm{CSR}$ input, $\mathrm{ROA}=$ return on assets, Lever $=$ financial leverage which is long-term debt divided by total assets of the ending period, $\mathrm{MB}=$ growth opportunity which is market value of equity divided by book value of equity, Beta $=$ Beta risk, Size $=$ firm size which is natural log of market value of equity, OCF = operating cash flows which is current period's operating cash flows divided by total assets of the beginning period, M_Stock = shareholdings of managers which is the shareholdings of corporate managers or group firm's managers, D Rate $=$ the ratio of a director concurrently served as a manager which is the number of director concurrently served as a manager divided by total numbers of directors. 


\subsection{The Relationship Between Current CSR, Mispricing and Accounting Quality}

Table 6 analyzes the association between current period's CSR and accounting quality of a company. From Model 6 in Table 6 , the findings show that accounting quality is positively related to current period's CSR, and it shows that if companies have higher current period's CSR input, it does a poor accounting quality owned. The possible reason is that the effect of CSR input on company is more longer period.

Considering endogeneity problem in accounting quality, this study adds prior period accounting quality to be regarded as an explanatory variable to analyze its effect on current accounting quality. In Model 8 in Table 6, we also find that after considering prior accounting quality, there is a positively association between accounting quality and current CSR cost, and it shows that the company with a higher current period's CSR, it has a poor accounting quality.

Overall, from Table 5 and Table 6, we find that the firm with higher current period's CSR input, its current accounting quality is poor, and the firm with higher prior period's CSR input, its current accounting quality is better. The possible reason is that the firm that performs social responsibility at the early stage will induce higher cost and then decrease profit, which imply that the effect of CSR cannot be achieved in short-term period but its effect will be more obvious in the next period. In other words, the higher
CSR input can increase the market competition of company, and then increase the firm's profit. Meanwhile, this effect will sustain to next period, and therefore, our result support hypothesis 2 .

\subsection{The Relationship Between Current CSR and Mispricing and Accounting Quality}

Table 7 shows the results of after controlling for the interaction between accounting quality and CSR. From Model 9 and Model 10 in Table 7, we find that both current CSR input and prior CSR input are negatively related to mispricing, meaning that the firm which CSR input is higher, its stock price is more unlikely to be underpriced. We also find that the measure of accounting quality is negatively related to its valuation by market, indicating that the company with poor accounting quality is less likely to be under-valued by market due to information asymmetry.

Study by the hypothesis 3 of the biotech and pharmaceutical industry CSR, there is some interaction between the market and the company's accounting evaluation of the quality, showing CSR to expose the higher level of information, it means enterprises to pay attention to their stakes human communication and the social responsibilities, and therefore CSR performance better. Overall, from Model 9 and Model 10 of Table 7, the empirical results of this study support the hypothesis 3 .

Table 7. The relationship between current CSR and mispricing after controlling for accounting quality.

\begin{tabular}{|c|c|c|c|c|c|c|}
\hline \multicolumn{7}{|c|}{$\begin{array}{l}\text { Misprice }_{i t}=a_{0}+a_{1} \text { CSR }_{i t}+a_{2} A Q_{i t}+a_{3} \text { CSR }_{i t} A Q_{i t}+a_{4} \text { ROA }_{i t}+a_{5} \text { Lever }_{i t}+a_{6} M B_{i t}+a_{7} \text { Beta }_{i t}+a_{8} \text { Size }_{i t}+a_{9} O C F_{i t}+a_{10} M_{-} \text {Stock }_{i t}+a_{11} D_{-} \text {Rate }_{i t}+\text { Year }+e_{i t} \\
\text { Misprice }_{i t}=a_{0}+a_{1} \text { CSR }_{i t-1}+a_{2} A Q_{i t}+a_{3} \text { CSR }_{i t-1} A Q_{i t}+a_{4} \text { ROA }_{i t}+a_{5} \text { Lever }_{i t}+a_{6} M B_{i t}+a_{7} \text { Beta }_{i t}+a_{8} \text { Size }_{i t}+a_{9} \text { OCF }_{i t}+a_{10} M_{-} \text {Stock }_{i t}+a_{11} D_{-} \text {Rate }_{i t}+\text { Year }_{i t}+e_{i t}\end{array}$} \\
\hline \multirow[t]{2}{*}{ Variables } & \multicolumn{3}{|l|}{ Model 9} & \multicolumn{3}{|l|}{ Model 10} \\
\hline & Coef. & t value & $P>t$ & Coef. & t value & $P>t$ \\
\hline$\overline{C S R}$ & -0.0165 & -2.67 & 0.0080 & & & \\
\hline $\mathrm{CSR}_{\mathrm{it}-1}$ & & & & -0.0188 & -2.19 & 0.0300 \\
\hline $\mathrm{AQ}$ & -0.9686 & -2.06 & 0.0041 & -1.2347 & -2.26 & 0.0250 \\
\hline CSR*AQ & -0.0164 & -0.23 & 0.8150 & 0.0389 & 0.39 & 0.6950 \\
\hline ROA & 0.0066 & 1.25 & 0.2130 & 0.0022 & 0.39 & 0.6930 \\
\hline Lever & 0.3379 & 0.90 & 0.3700 & 0.3863 & 0.92 & 0.3590 \\
\hline MB & -0.0010 & -1.99 & 0.0470 & -0.0008 & -1.36 & 0.1760 \\
\hline Beta & 0.1733 & 1.78 & 0.0770 & 0.1820 & 1.34 & 0.1830 \\
\hline Size & 0.0315 & 0.73 & 0.4670 & 0.4951 & 0.96 & 0.3400 \\
\hline $\mathrm{OCF}$ & -1.1641 & -2.29 & 0.0230 & -0.9769 & -1.61 & 0.1100 \\
\hline M_Stock & 0.0422 & 1.93 & 0.0550 & 0.0529 & 2.05 & 0.0442 \\
\hline D_Rate & -0.0084 & -3.23 & 0.0010 & -0.0086 & -2.74 & 0.0070 \\
\hline Year & -0.0393 & -1.62 & 0.1070 & -0.0086 & -0.89 & 0.3760 \\
\hline _Cons & 0.8046 & 1.11 & 0.2690 & 0.4515 & 0.53 & 0.5990 \\
\hline No. of obs. & 238 & & & 238 & & \\
\hline Prob $>F$ & 0.0000 & & & 0.0000 & & \\
\hline R-squared & 0.1863 & & & 0.1756 & & \\
\hline Adj R-squared & 0.1386 & & & 0.1160 & & \\
\hline
\end{tabular}

Variable definition:

$\mathrm{AQ}=$ accounting quality, $\mathrm{CSR}=\mathrm{CSR}$ input, $\mathrm{CSR} * \mathrm{AQ}=\mathrm{CSR}$ multiplied by the accounting quality, $\mathrm{ROA}=$ return on assets, Lever $=$ financial leverage which is long-term debt divided by total assets of the ending period, $\mathrm{MB}=$ growth opportunity which is market value of equity divided by book value of equity, Beta $=$ Beta risk, Size $=$ firm size which is natural log of market value of equity, OCF $=$ operating cash flows which is current period's operating cash flows divided by total assets of the beginning period, M_Stock = shareholdings of managers which is the shareholdings of corporate managers or group firm's managers, D_Rate $=$ the ratio of a director concurrently served as a manager which is the number of director concurrently served as a manager divided by total numbers of directors. 


\section{Conclusions}

In today's rapid changing environment, the business structures become more complex and diverse. The biotechnology and medical industries have the properties of high risk and long-period profitableness. Hence, it is more essential and necessary to accurately evaluate the value of a company for market investors and entrepreneurs. The appropriate application of CSR strategy may generate reputational effects, increase operating incomes and decrease financial risks. To evaluate enterprise value accurately, we need to understand the definition of enterprise value and evaluating methodology initially.

This paper first examine whether enterprise stock prices will be less likely to be under-valued by the market when companies input higher CSR. Secondly, we argue whether accounting quality will be much higher when the companies get higher CSR. Finally, under controlling for companies' accounting quality, we discuss whether the companies which input higher CSR will not be wrongly evaluated by the market investors.

The empirical results show that companies with higher current and prior periods' CSR inputs make their stock price less likely to be under-valued by the market. The empirical results are consistent with our expectations, showing that companies with higher CSR input at prior period may have better accounting quality, but a higher CSR input in current period may decrease current accounting quality. This finding implies that the effect of CSR cannot be achieved in short-term period but in the future. Finally, by controlling the interaction between company's accounting quality and CSR, we also find that the companies with higher CSR at current and lagged-one periods will be less likely to be under-valued by the market for their stock prices.

Currently, Taiwan law norms of CSR is not yet complete, in the fulfillment of CSR with international standards on information disclosure is still a gap, government and related organizations may require the companies to adopt internationally practices of the CSR report or the development of standardized reports. At the same time, the CSR that is provided in the annual financial statements will enable companies to create high-quality competitive society and the environment.

\section{References}

[1] Argenti, P. A., and B. Druckenmiller. 2004. Reputation and the corporate brand. Corporate Reputation Review 6(4), 368-374.

[2] Baker, M., and J. Wurgler. 2002. Market timing and capital structure. Journal of Finance 57(1), 1-32.

[3] Bowen, H. R. 1953. Social responsibilities of the businessman. New York: Harper and Brothers.

[4] Carroll, A. B. 1991. The pyramid of CSR: Toward the moral management of organizational stakeholders. Business Horizons 34(4), 39-48.
[5] Chen \& Tsao. 2008. Is there a social responsibility to be a good stock? Financial and stock research links. OTC Monthly 136,106-121.

[6] Cho, S. Y., C. Lee, and R. J. Pfeiffer. 2013. CSR performance and information asymmetry. Journal of Accounting and Public Policy 32(1), 71-83.

[7] Dhaliwal, D. S., O. Z. Li, A. Tsang, and Y. G. Yang. 2011. Voluntary nonfinancial disclosure and the cost of equity capital: The initiation of CSR reporting. The Accounting Review 86(1), 59-100.

[8] Dhaliwal, D. S., S. Radhakrishnan, A. Tsang, and Y. G. Yang. 2012. Nonfinancial disclosure and analyst forecast accuracy: International evidence on CSR disclosure. The Accounting Review 87(3), 723-759.

[9] Dhaliwal, D. S., O. Z. Li, A. Tsang, and Y. G. Yang. 2014. CSR disclosure and the cost of equity capital: The roles of stakeholder orientation and financial transparency. Journal of Accounting and Public Policy 33(40), 328-355.

[10] Dechow, P. M., and I. D. Dichev. 2002. The quality of accruals and earnings: The role of accrual estimation errors. The Accounting Review 77 (4), 35-59.

[11] Dittmar, A., and R. Dittmar. 2008. The timing of financing decisions: an examination of the correlation in financing waves Journal of Financial Economics 90(1), 59-83.

[12] Elliott, W. B., J. Koëter-Kant, and R. S. Warr. 2008. Market timing and the debt-equity choice. Journal of Financial Intermediation 17(2), 175-197.

[13] Fombrun, C. J. N. A. Gardberg, and M. L. Barnett. 2000. Opportunity platforms and safety nets: Corporate citizenship and reputational risk. Business and Society Review 105(1), 85-106.

[14] Friedman, M. 1970. The social responsibility of business is to increase its profits. New York Times Magazine 3(13), 32-33.

[15] Goodpaster, K. E. 1991. Business ethics and stakeholder analysis. Business Ethics Quarterly 1(1), 53-73.

[16] Kim, W., and M. S. Weisbach. 2008. Motivations for public equity offers: An international perspective. Journal of Financial Economics 87(2), 281-307.

[17] Kim, Y., M. Park, and B. Wier. 2012. Is earnings quality associated with CSR? The Accounting Review 87(3), 761-796.

[18] LaFond, R., and R. Watts. 2008. The information role of conservatism. The Accounting Review 83 (2), 47-478.

[19] Lee, G., and R. Masulis. 2009. Seasoned equity offerings: Quality of accounting information and expected flotation costs Journal of Financial Economics 92(3), 443-469.

[20] Perrini, F., and A. Tencati. 2006. Sustainability and stakeholder management: The need for new corporate performance evaluation and reporting systems. Business Strategy and the Environment 15(5), 296 -308.

[21] Rajaopal, S., and M. Venkatachalam. 2011. Financial reporting quality and idiosyncratic return volatility. Journal of Accounting and Economics 51(1-2), 1-20.

[22] Schnietz, K. E., and M. J. Epstein, 2005. Exploring the financial value of a reputation for CSR during a crisis. Corporate Reputation Review 7(4), 327-345. 
[23] Siegel, D., \& Vitaliano, D. 2007. An empirical analysis of the strategic use of corporate social responsibility. Journal of Economics and Management Strategy 17, 773-792.

[24] Simpson, W., and T. Kohers. 2002. The link between social and financial performance: Evidence from the banking industry. Journal of Business Ethics 35(2), 97-109.

[25] Thomas, A., \& Williams, G. R. 1991. A strategy to provide retirement benefits for international transferees in a global company. Benefits and Compensation International, 10, 2-7.

[26] Tsukamoto, S. W. 2005. An economic approach to business ethics: Moral agency of the firm and the enabling and constraining effects of economic institutions and interactions in a market economy. Journal of Business Ethics 60(1), 75-89.
[27] Tucker, L., and T. C. Melewar. 2005. Corporate reputation and crisis management: The threat and manageability of anti-corporatism. Corporate Reputation Review 7(4), 377-386.

[28] Warr, R., W. Elliott, J. Koëter-Kant, and Ö. Öztekin. 2012. Equity mispricing and leverage adjustment costs. Journal of Financial and Quantitative Analysis 47(3), 589-616.

[29] Xie, B., W. Davidson III, and P. DaDalt. 2003. Earnings management and corporate governance: The role of the board and the audit committee. Journal of Corporate Finance 9(3), 295-316. 